\title{
不活性ガス濃度法による気体流量の測定
}

\author{
井伊谷鋼一・田中信寿 -木村松弘 \\ 京都大学工学部 京都市左京区吉田本町 \\ (昭和 44 年 7 月 4 日 受付)
}

\section{Gas Flow Rate Measurement by Inert Gas Concentration Method}

\author{
Koichi Innoya, Nobutoshi Tanaka and Matsuhiro Kimura \\ (Faculty of Engineering, Kyoto University, Kyoto)
}

(Received July 4, 1969)

The concentration method for flow rate measurement is substantially distinct from other methods. It is often used to measure flow rate of water through a water-turbine of power station, but few reports of measuring gas flow rate by the concentration method have been published. Some experimental results of flow rate measurement of air by this method is herein presented. The flow rate of air is obtained by measuring both injection rate of inert gas and inert gas concentration of mixed gas, and then substituting these values into eq. (1) or (2).

The accuracy of this method depends on whether the inert gas is perfectly mixed or not. In other words, after injected inert gas is mixed with the main flow through a mixing part, the inert gas concentration must be uniform over a sampling plane normal to the direction of flow. In this work, it is examined how long distance from an elbow is required in order to attain a stable concentration profile, when an elbow is used as a mixing part and the flow rate of air is 0.5 to $1.5 \mathrm{~m}^{3} / \mathrm{min}$. in $1 \frac{1}{2}, 2,2 \frac{1}{2}$ and 3 inches standard gas pipes.

Consequently, the stable concentration profile is attained at about $80 \mathrm{~cm}$ downstream from an elbow, and its distance does not depend on both the main flow rate of air and the pipe diameter. The accuracy of this method using an elbow is within $\pm 1 \%$. The dispersion of measured values is within $\pm 2 \%$ in this work. In spite of some insufficient results, this work may be the knowledge to measure gas flow rate by the concentration method.

\section{1. まえがき}

流量測定は工業計測における重要な計測の1つであ り, 古くから各方面の工業分野で種々の流体について いろいろの方法が行なわれてきた。最近は工業分野の 多様化とともに，自動制御の普及によって流量計測も 複雑, 多岐にわたり, 各種の特徴ある方式が数多く使 用されている11.

それらは流量測定の目的により選択されねばならな いが，工業分野での流量計測の多くは絞り流量計を用 いているよらである2). この方法の短所は絞り部の前 後にかなりの直管部を要すること, 絞りによって圧損
を生ずること，管部のよごれによる影響や絞り部への 異物の付着による影響などの経時誤差, および取り付 け時や製作時に生ずる固有誤差などが存在すること， などである。したがって正確な測定を保持するために は検定を行なら必要があるが，その検定はかなりめん ぞうである。また，大流量の測定や粉じん気流の測定 に使いにくいことも短所であろうら。

ここで述べる不活性気体注入による気体流量測定法 は物質を流して流量を測定する方法として分類するこ とができ，その内で濃度法といわれるものである。こ れは上流で注入した物質の濃度を十分混合したと思子 れる下流に执いて測定し，その濃度から流量を決定す 
る方法であるが，塩水を用いる塩水濃度法は 古くから水力発電所の水車流量の測定に用い られている。このように, 濃度法が液体の流 量計測飞使われた例は多くあるが，気体の流 量計測使われた例は少ない上らである.

J. F. Kemp は脈動流の流量測定を主目的 として濃度法を空気の定常流执よび脈動流の 流量測定に応用している3 ${ }^{3)}$. 使用している管 の径は約 $12 \mathrm{~cm}$ であり, 流量も相当大きい. 本報告では不活性気体の混合を完全にするこ とによって注入法やサンプリング法を簡単に しているのに対して, Kemp の研究では混合 が十分に促進されなくても測定が可能である ように不活性気体の注入法やサンプリング法 にかなりのくらうをしている。

この測定法の得失を絞り流量計との比較を 念頭に执いて考兄ると, 絞り流量計のように 直管部を必要とせず, 施回流などの流れの乱 れがあっても関倸なく，むしろ，そのような 流れの乱机を積極的に利用することができる。 また, 検定のさいには, 濃度分析計を独立に 校正することによって流量計測の検定が簡単に行なえ る.ささらに, 水力発電所の水車流量測定にみられるよ らに大流量測定への可能性を含んでいる。いっぽう， 短所としては，（イ）異種物質を注入するために流体 が污染をきらうときには使えない。（口）濃度測定時 には定常的に不活性物質を注入するため, 割合多くの 不活性物質を必要とする。（分）濃度分布が管断面で 均一でないと測定誤差となる。（イ）と（ロ）の難点に ついては, 濃度測定機器の発達によって ppm 程度の 濃度分析が可能になれば解決されるだろらし, この測 定法の使用範囲が拡大されるだろう。したがって， (八)の短所がこの計測法を実施するときの重要問 題 となる。

この点に注目し，従来，使用されたことの少ない気 体流量測定の場合について実験を行ない，測定䛊差お よび精度の検討を行なった，特に工業配管で常時使用 されるエルボに注目し，不活性ガスを含んだ流体がエ ルボを通過した後, どの程度の距離で混合が完了し, ほぼ安定した濃度分布を達成するかを求めた。なた， 濃度分布の不均一による測定誤差も考光た。同時に， この結果は管路中における流体混合についての1つの 知見を与えるものとい光る.

\section{2. 測定原理と実験の概要}

濃度法による流量測定は上流において不活性気体を

(1) : inlet nozzle

(2): injection point

(3) : mixing part

(4): sampling point

(5) : gas analyzer

(6): inclined-tube manometer of ethanol

(7) : differential pressure type flow-meter

(8): Argon gas bomb

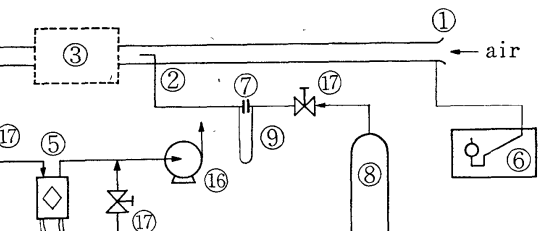

(9) : Göttingen precision manometer

(10) : turbo-blower

(11) : stop valve

(12) : filter

(13) : voltage supply

(14) : pen recorder

(15) : flexible-pipe

(16) : vacuum-pump

(17) : needle-valve

Fig. 1 Schematic diagram of experimental set-up

定常的に注入し，十分混合したと思われる下流におい て小量の流体をサンプリングし，その濃度を測定する。 このとき, 不活性気体の流量を $q\left[\mathrm{~m}^{3} / \mathrm{min}\right]$, サンプ リングした混合気体の濃度を $c[\mathrm{vol} \%]$ とすれば，不 活性気体を注入する前の管路の流量 $Q\left[\mathrm{~m}^{3} / \mathrm{min}\right]$ は次 のように物質収支から求まる。

$$
Q=(100 q / c)-q
$$

多くの場合, 濃度法では管路の流量Qに比してごく少 量の不活性成分を注入するので $Q \gg q$ であるから上式 は次式のように考光てよい。

$$
Q=100 q / c
$$

これが濃度法による測定原理である。

この測定法の説明を兼ねて本実験のフローシートを

Fig. 1 亿示寸. 不活性気体（アルゴンガス）を二 ドルバルブの調節によって定常的に流す．あらかじめ 湿式ガスメータで校正した絞り管を用いてアルゴンガ ス流量を測定する。この絞り管の差圧はゲッチンゲン 微差圧計を用いて読み取る。内径 $4 \mathrm{~mm}$ の管を用い て管中央に执いて下流向きにアルゴンガスを注入する。 不活性気体を十分混合させるために設けた混合部を通 過した流体を適当な所で連続的に真空ポンプでサンプ リングし，ガス分析計に流す．本実験で用いた連続ガ ス分析計は白金線をクロス形にブリッジに組んだ熱伝 導率測定方式の分析計である。連続的にガス濃度を測 定することができるので，濃度が安常になったことを 
確かめることができる. 性能は 0〜 5 vol \% Ar in Air

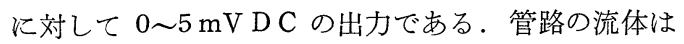
空気でターボブロワにより吸引し， 2 in ガス管用の入 ロノズル (ガラス製)によって流量湘定を同時に行な い, 濃度法による流量測定值と比較する. 空気流量は $0.5 \sim 1.5 \mathrm{~m}^{3} / \mathrm{min}$ であり, ガス分析計の性能から,ア ルゴン濃度が 1 vol\% 程度になるように，アルゴン ガス注入量を調節した。また，ガス分析計へのサンプ リング量は $0.5 \mathrm{l} / \mathrm{min}$ である.

\section{3. 入ロノズルの校正}

まず，オリフィスを自家製の水置換形ガスホールダ (内容積 $0.77 \mathrm{~m}^{3}$, 断面積 $0.64 \mathrm{~m}^{2}$ ) を用いて校正し, 次に，そのオリフィスと入口ノズルを直列におくこと 飞よって入口ノズルの校正を行なった．その校正結果 を Fig. 2 に示す。横軸は $\Delta p / \rho$ で $\Delta p$ は入口ノズル の負圧であり，エタノール封入傾斜管形微圧力計の読 及 $[\mathrm{cm}]$ である。 $\rho$ は空気密度 $\left[\mathrm{kg} / \mathrm{m}^{3}\right]$ である。な

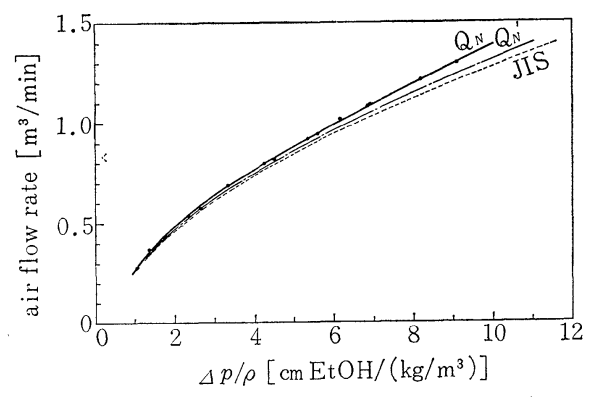

$\ldots$ : calibration curve by gas holder and orifice

- experimental values by gas holder and orifice

......... : calibration curve by inert gas concentration method

..... : calibration curve bý JIS

Fig. 2 Calibration curve of inlet nozzle

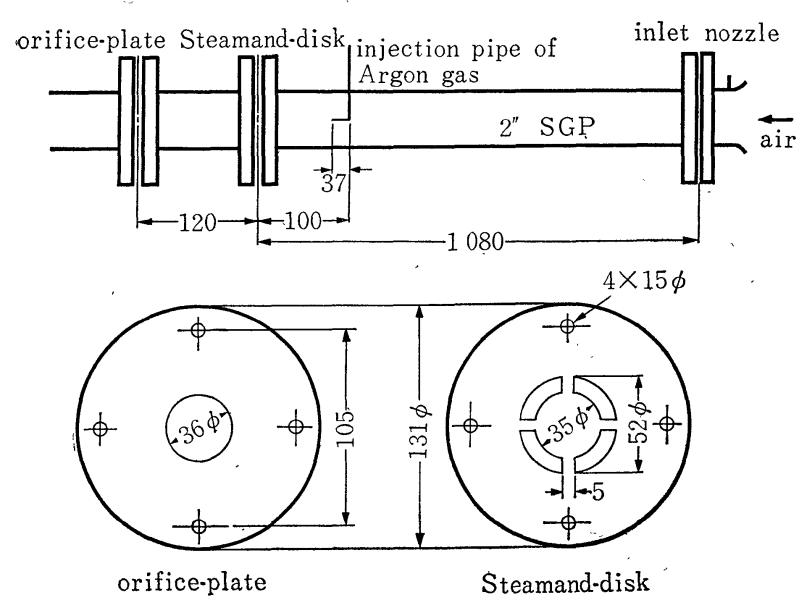

Fig. 3 Schematic diagram, when an orifice-plate and a Steamanddisk are used as mixing part (2 in SGP)
お，この微圧力計の拡大率は 10.5 倍である. Fig. 2 中の破線は JIS $\left.{ }^{4}\right)$ の計算式によって求めた校正曲線で ある.これらの 2 つ校正曲線では 4〜6\% の系統的 差違がある．その原因としては入口ノズルがガラス製 であるために JIS の寸法規格通り作られていないこ とや，オリフィスとガスホールダによる校正操作が複 雑であったことなどが考えられる。

\section{4. 濃度法による流量測定の精度}

不活性気体を注入する上流部から，混合気体をサン プリングする下流部までの間で十分な混合が達成され れば，濃度法による流量測定の原理がみたされ，(1) 式ないし，(2)式で管路の流量が測定できる.そこで, Fig. 3 に示すようなステアマンドディスク状の板（上 流側）とオリフィス板状の板 (下流側) とを 2 in ガ ス管へそら入し,オリフィス板から $35 \mathrm{~cm}$ の距離を おいてサンプリングし, 濃度を測定した。サンプリン グ位置を半径方向に 4 点移動した. 管中央 $(x / R=0)$, 中央から半径の $1 / 3$ の位置 $(x / R=1 / 3)$, 中央から半 径の $2 / 3$ の位置 $(x / R=2 / 3)$, 管壁 $(x / R=1)$ の 4 点 である・

空気流量を $1.45,1.22,0.97,0.75,0.57 \mathrm{~m}^{3} / \mathrm{min}$ の 5 点を設定し，これに近い流量値になるよらに空気 流量を調節した・アルゴンガス流量は前述のと扣り,混 合ガスのアルゴン濃度が $1 \mathrm{vol} \%$ 近くになるように 調節した. 測定值 (アルゴンガス流量 $q \mathrm{~m}^{3} / \mathrm{min}$ とサ ソプリング混合気体濃度 $c$ vol \%) から（1)式により 空気流量 $Q_{c} \mathrm{~m}^{3} / \mathrm{min}$ を計算した。この結果を入口ノ ズルによる流量 $Q_{N}$ との相対值 $\left(Q_{c}-Q_{N}\right) / Q_{N}$ の形 で Fig. 4 に示す. 付字 $c$ は濃度法によるもの, 付字 Nは入口ノズルによるものであることを示す。

半径方向の濃度分布の一例を空気流量 $0.97 \mathrm{~m}^{3} / \mathrm{min}$ の場合について Fig. 5 に 示す。これでは，混合が管断面で，まだ 十分に均一でないので管断面について平 均濃度 $\bar{c}$ を求めて濃度分布が均一である とじたときの $Q_{N}$ と $Q_{c}$ の関係を求める 必要がある。それを流量 $0.97 \mathrm{~m}^{3} / \mathrm{min}$ の場合について説明する。

まず,実験のさいの流量 $Q_{N}$ は0.97 $\mathrm{m}^{3} /$ min 近辺の值ではあるが, 正確に 0.97 $\mathrm{m}^{3} / \mathrm{min}$ でないし, アルゴンガス流量 $q$ も括の扮のの測定について $9.798 \mathrm{l} / \mathrm{min}$ 近辺の值ではあるが正確に $9.798 \mathrm{l} / \mathrm{min}$ でない、そのため, 実験値として得られ た濃度 $c$ を $Q_{N}=0.97 \mathrm{~m}^{3} / \mathrm{min}, q=9.798$ 


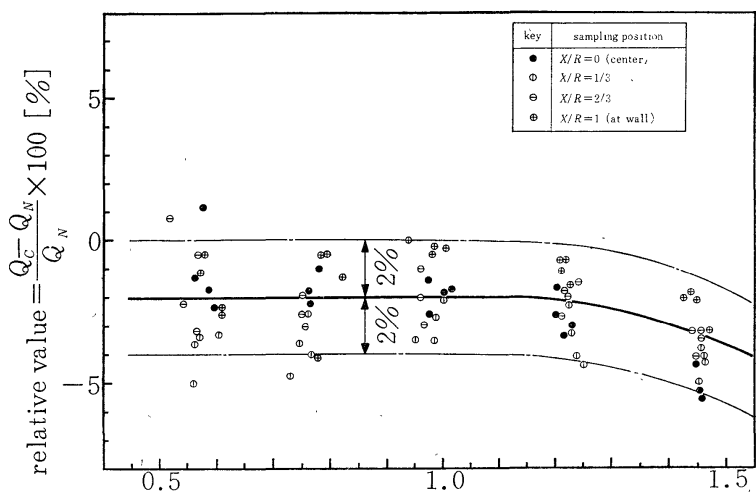

air flow rate $Q_{N}$, measured by inlet nozzle $\left[\mathrm{m}^{3} / \mathrm{min}\right]$

Fig. $4 Q_{c}$ vs. $Q_{N}(2$ in SGP)

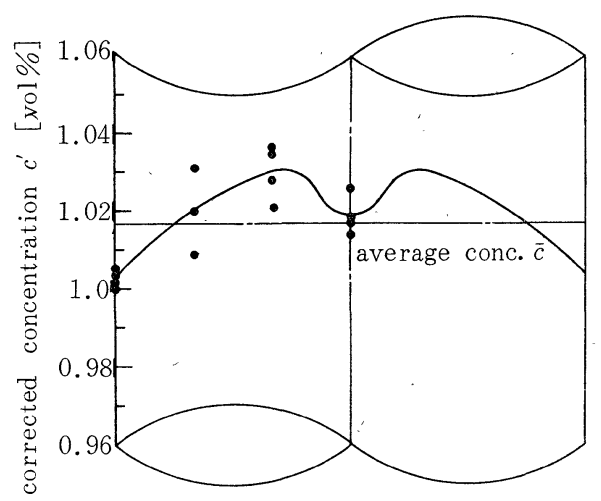

Fig. 5 Radial concentration profile (when $Q_{N}=0.97 \mathrm{~m}^{3} / \mathrm{min}$ in 2 in $\mathrm{SGP}$ )

$l / \min ($ 混合気体の濃度が 1 vol \% になるというこ と）の状態での濃度 $c^{\prime}$ に修正する。的 は相対的に実 験值 $c$ から計算できるとすると，(1)式から,

$$
\frac{c^{\prime}}{c}=\left(\frac{9.798}{970+9.798}\right) /\left(\frac{q}{q+Q_{N}}\right)=\frac{q+Q_{N}}{100 q}
$$

(3) 式によって求めた修正濃度 $c^{\prime}$ を点つら゙りしたも のが Fig. 5 である.

また，半径方向の濃度分布と速度分布から平均濃度 $\bar{c}$ は次式によって求悉る。

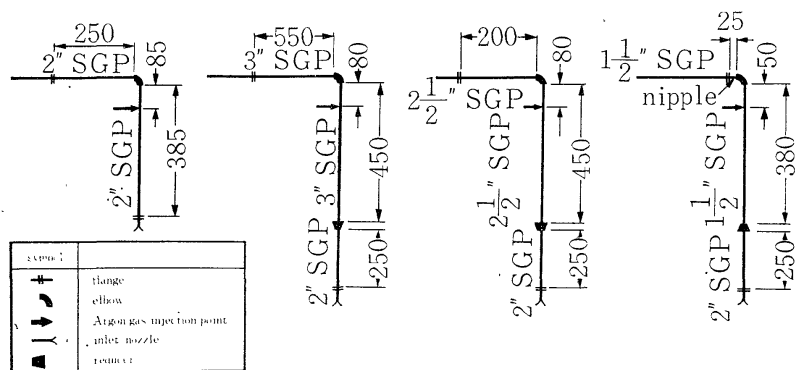

Fig. 6 Schematic diagran of pipe line, when an elbow is used as mixing part

$$
\bar{c}=\int_{0}^{R} 2 \pi c u r d r / \pi R^{2} \bar{u}
$$

ここで半径方向の速度分布は均一であると 仮定できるとし，また実測值は $r=0, R / 3$ ， $2 R / 3 ， R$ での值だけであるから，それら の点を折線で結ぶと, (4)式の積分は次の 上万求劣。

$$
\bar{c}=\left(c_{0}+4 c_{1}+8 c_{2}+5 c_{3}\right) / 18
$$

付字 $0,1,2,3$ は执のおの, $r=0, R / 3$, $2 R / 3, R^{\prime}$ の位置住対応する．（5）式によ って求めた $\bar{c}$ を Fig. 5 に括いて鎖線で示 す。

この平均濃度 $\bar{c}$ によって空気流量を求め ると，

$$
Q_{c}=979.8 / \bar{c}-9.798
$$

また，このときの入ロノズルによる空気流量は 0.97 $\mathrm{m}^{3} / \mathrm{min}$ であるから相対值 $\left(Q_{c}-Q_{N}\right) / Q_{N}$ は次式で求 まる。

$$
\left(Q_{c}-Q_{N}\right) / Q_{N}=(100 / \bar{c}-100) / 99
$$

他の流量設定值 $\left(1.45,1.22,0.75,0.57 \mathrm{~m}^{3} / \mathrm{min}\right)$ についても同様にして $\left(Q_{c}-Q_{N}\right) / Q_{N}$ を求めて連衫た ものが Fig. 4 の実線である. 半径方向の流速分布が 均一であるといら仮定があるが，これが濃度分布が均 一であるときの $Q_{c}$ と $Q_{N}$ の関係を与兄る。この実 線に基づいて, 濃度法による測定値 $Q_{c}$ が正しいとし て入ロノズルの校正曲線を求めたものが Fig. 2 の鎖 線である。

濃度法による測定值と入ロノズルによる測定値とで は数\%の系統的差違がある。これが入ロノズルの校正 曲線（Fig. 2 の実線）が正しくないのが，あるいは， 他鿌因があるのかわからない，また，本実験装置で の濃度法による流量測定の精度は $2 \%$ 以内である。

\section{5. エルボを混合部としたときの流量測定}

濃度法による流量測定を有効に適用するためには， 不活性気体を十分に混合させるものが必要である。こ こでは工業配管で常時使用されるエルボに注目し， エルボを通過した流体がぞの程度の距離で混合を 完了するか実験を行なった。使用した管路の管径

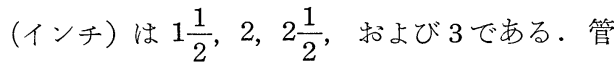
路の構成を記号的に Fig. 6 に示す.アルゴンガ スの注入は管中央で下流向きに行ない，またサン プリングは管中央で行なった。

3 in 管についてサンプリング距離（エルボか らサンプリング位置までの距離）と流量測定值と 


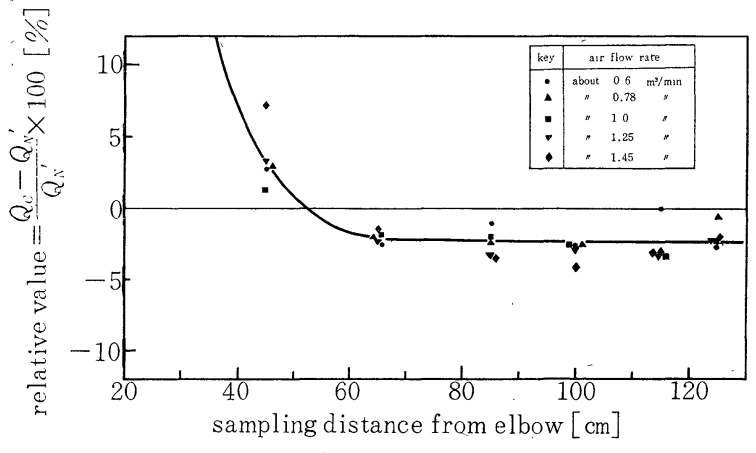

Fig. 7 Effect of sampling distance ( 3 in SGP)

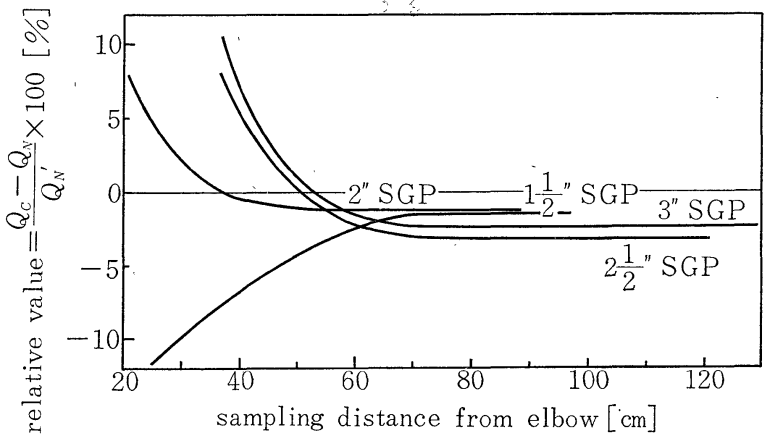

Fig. 8 Effect of sampling distance

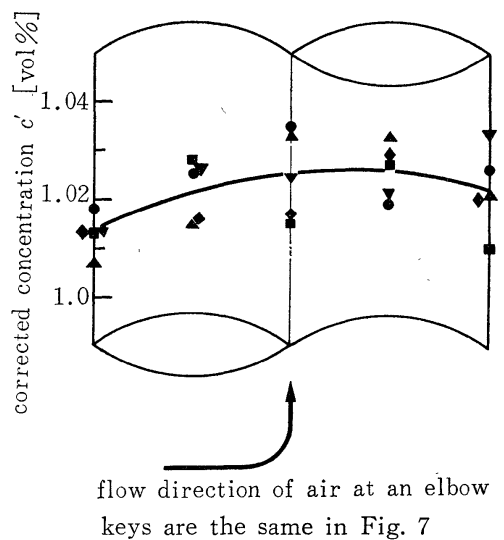

Fig. 9 Radial concentration profile, when an elbow is used (in 3 in SGP at $135 \mathrm{~cm}$ downstream from an elbow)

の関係を Fig. 7 に示す。たて軸は入ロノズルによる 流量 $Q_{N}{ }^{\prime}$ と濃度法に上る流量 $Q_{c}$ の相対值である。 入口ノズルによる流量として $Q_{N}$ の代わりに $Q_{N}{ }^{\prime}$ を 使ったのは，入口ノズルの校正曲線として Fig. 2 の 鎖線を使ったからである。つまり，前章で求めた濃度 法による入口ノズルの校正曲線を使った。他の管径に ついての結果を，実験点を省いて Fig. 8 亿示す。ま
た， 3 in 管の場合の半径方向の濃度分布を Fig. 9 に示す。これはエルボから $135 \mathrm{~cm}$ 離れた位置 のものである. 修正濃度 $c^{\prime}$ の求め方は前章と同 じである.

これらの実験結果から,どの管径についても,流 量の大小に関係なくエルボから約 $80 \mathrm{~cm}$ の距離 で混合がほぼ完了したとみることができて，濃度 法による流量測定が可能となる．流量の大小にか かわらず，ほ添同じサンプリング距離をとればよ いことについては次のように定性的に説明できる だろう。エルボ部で生ずるかく乱は流速の増大と ともに激しくなり,そのため, その後に混合を完了 するに要する時間は短くなる。いっ涩う,流速が増 大すると同一の距離を通過するに要する時 間は短くなる・けっきょく混合に要する距 離は流量の大小にかかわらず, ほぼ一定に なる. $1 \frac{1}{2}$ in 管について他の管径のものと 傾向の異った曲線を示しているが，これは Fig. 6 に示すようにアルゴンガスの注入 点が他のものよりェルボに近かったためで あろう。これまでの測定ではアルゴンガス の注入方向は下流向きであったが，上流向 きに注入した場合について，2 in 管で実 験を行なったが，下流向きに注入した場合 とほぼ一致した。

入ロノズルの校正曲線として, Fig. 2 の鎖線（濃 度法沙流量测定が正しいとして求めた校正曲線） を用いているので, Fig. 7，8 亿拈いて十分なサンプ リング距離では測定值 $\left(Q_{c}-Q_{N}{ }^{\prime}\right) \times 100 / Q_{N}{ }^{\prime}$ は00付 近に集るるはずである. Fig. 7，8 でそのようになら ない理由としては, Fig. 4 亿预汀る実験值から $Q_{c}$ と $Q_{N}$ の関係を求めるさいに半径方向の流速分布は一定 であるといらょらな不完全な仮定を行なっているため に Fig. 2 の校正曲線（鎖線）の不正確さ，あるいは エルボ通過後のサンプリング点で濃度分布が完全に均 一になっていないこと，末た，測定值の数が少ないこ となどが考兄れる。しかし，Fig. 9 をみると，ほぼ 均一な濃度分布を示しているので, 濃度分布の不均一 さが主な原因ではなく，校正曲線の不正確さが原因で あると考光る。

参考のために，エルボを 2 個とら入したときのサン プリング距離と相対値 $\left(Q_{c}-Q_{N}{ }^{\prime}\right) / Q_{N}{ }^{\prime}$ の関係を Fig. 10 に示す。な抢, サンプリング距離は下流側のエル ボからの距離である。また，このときの管路の構成を 図中に示す。 
6. む す び

濃度法による流量測定の要点はどの程度, 不活性成分が均一飞混合するかといらこと であるが，それを工業配管でよく使用され るエルボについて，流体が空気の場合で害 験的に検討を行ない, エルボによって，か なり簡単に混合が促進されることがわかっ た。䈯密に考它れば, 半径方向に濃度分布 を均一にすることは不可能に近く，それが 濃度法による測定法の確かさの限界である 5. Fig. 9 の濃度分布にみられるよらに $\pm 1 \%$ 程 度の測定誤差が許されるのであ れば，濃度法による気体流量の測定をエル ボの前後を利用することによってできるで あろう。市た，測定精度も使用するガス分析計の性能 の向上によってかなり向上するであろら。

また，固気 2 相流に応用した場合や管径あるいは， 流量が大きくな゙った場合などについて検討を行ならこ とは残された課題の 1 つであるし，不活性ガスの注入 位置, 注入方法（たとえば, 半径方向にわたって多く の場所から注入する）あるいは，サンプリング法（本 実験では管中央の 1 点のみでサンプリングすると考光 た）の影響なども，この測定法の精度および操作を実 施するさいの難易度と共に検討されなければならない 問題であろら。

\section{記 号 説 明}

$c:$ concentration of inert (Argon) gas [vol \%] $c^{\prime}$ : corrected concentration of inert (Argon) gas

[vol \%]

$\bar{c}$ : average concentration of inert (Argon) gas [vol \%] $q:$ injection rate of inert (Argon) gas $\left[\mathrm{m}^{3} / \mathrm{min}\right]$

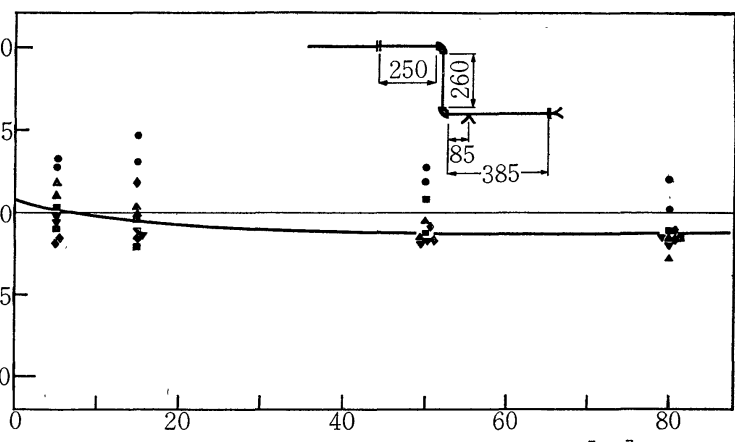

sampling distance from the second elbow $[\mathrm{cm}]$

schematic diagram, with same symbols in Fig. 6 keys are the same in Fig. 7

Fig. 10 Effect of sampling distance, when two elbows are used in 2 in SGP

$Q:$ flow rate of air $\left[\mathrm{m}^{3} / \mathrm{min}\right]$

$Q_{N}$ : flow rate of air with solid line in Fig. 2

$\left[\mathrm{m}^{3} / \mathrm{min}\right]$

$Q_{N}{ }^{\prime}$ : flow rate of air with chain line in Fig. 2

$\left[\mathrm{m}^{3} / \mathrm{min}\right]$

$Q_{c}$ : flow rate of air, measured by inert gas concentration method

$\left[\mathrm{m}^{3} / \mathrm{min}\right]$

$r$ : radial distance

[cm]

$R:$ radius

$u:$ air velocity $[\mathrm{cm} / \mathrm{s}]$

$\bar{u}:$ average velocity

1) 工業計測技術大系編集委員会編 : 流量 上, 下 (日刊 工業新聞社-昭 39)

2) 藤村昭雄 : 計測と制御，7-4，232（1968）

3) J.F.Kemp : J. of Basic Engineering (Trans. of the ASME), 83, 305 (1961)

4） JIS B 8330 送風機試験方法 